University of Nebraska - Lincoln

DigitalCommons@University of Nebraska - Lincoln

Agronomy \& Horticulture - Faculty Publications

Agronomy and Horticulture Department

7-1-2003

\title{
Divergent Selection for Seedling Tiller Number in Big Bluestem and Switchgrass
}

\author{
Alexander J. Smart \\ South Dakota State University \\ Kenneth P. Vogel \\ USDA-ARS, kvogel1@unl.edu \\ Lowell E. Moser \\ University of Nebraska-Lincoln, Imoser1@unl.edu \\ Walter W. Stroup \\ University of Nebraska-Lincoln, wstroup1@unl.edu
}

Follow this and additional works at: https://digitalcommons.unl.edu/agronomyfacpub

Part of the Plant Sciences Commons

Smart, Alexander J.; Vogel, Kenneth P.; Moser, Lowell E.; and Stroup, Walter W., "Divergent Selection for Seedling Tiller Number in Big Bluestem and Switchgrass" (2003). Agronomy \& Horticulture -- Faculty Publications. 42.

https://digitalcommons.unl.edu/agronomyfacpub/42

This Article is brought to you for free and open access by the Agronomy and Horticulture Department at DigitalCommons@University of Nebraska - Lincoln. It has been accepted for inclusion in Agronomy \& Horticulture -Faculty Publications by an authorized administrator of DigitalCommons@University of Nebraska - Lincoln. 


\title{
Divergent Selection for Seedling Tiller Number in Big Bluestem and Switchgrass
}

\author{
Alexander J. Smart,* Kenneth P. Vogel, Lowell E. Moser, and Walter W. Stroup
}

\begin{abstract}
Selection at the seedling stage in forage grass breeding would be extremely useful if seedling traits are highly heritable and correlated to desired agronomic traits. Objectives of this study were to determine the response to selection for high shoot weight and divergent selection for seedling tiller number in big bluestem (Andropogon gerardii Vitman) and switchgrass (Panicum virgatum $L_{\text {.) }}$ ) seedlings and obtain estimates of realized heritability for these traits. Base populations were breeding populations of 'Pawnee' big bluestem and 'Pathfinder' switchgrass. Divergent selection for single or multiple (three or more) tiller(s) 6 to $8 \mathrm{wk}$ after planting in a greenhouse produced four populations [big bluestem high seedling weight, multiple tiller (BBMT); big bluestem high seedling weight, single tiller (BBST); switchgrass high seedling weight, multiple tiller (SWMT); and switchgrass high seedling weight, single tiller (SWST)], which were planted in isolated polycross nurseries. Seed from polycross nurseries was used to conduct a second cycle of selection. Populations were evaluated in greenhouse studies for fresh weight and tiller number of seedlings. Seedling fresh weight was increased in BBST and SWST Cycle 2 populations, and divergent selection for tiller number resulted in populations significantly different from the base population. Realized heritability estimates for seedling tiller number in big bluestem and switchgrass were 0.26 and 0.23 , respectively. The effect of genetic modification of seedling tiller number and shoot weight on establishment under field conditions and on mature plant phenotypes will need to be determined.
\end{abstract}

$\mathrm{G}$ RASS DEVElopMental morphology determines the expression of desirable traits of species utilized as forage. Most grass breeding programs are limited in their selection pressure by the limited number of plants that can be evaluated in spaced plant nurseries. Selection at the seedling level would be extremely useful if seedling traits were correlated to mature plant characteristics because more plants could be easily evaluated in the greenhouse (Hayward and Lawrence, 1970; Lawrence 1979a).

Selection at the seedling stage has been shown to be useful in improving traits including seedling vigor by selecting for high seedling weight in several legumes (Twamley, 1974; Simons, 1990; Xie and Mosjidis, 1995) and in cool-season and warm-season grasses (Trupp and Carlson, 1971; Glewen and Vogel, 1984). Nelson and Sleper (1980) reported that tall fescue (Festuca arundinacea Schreb.) seedlings varied greatly in number of tillers and yield per tiller. Genotypes of tall fescue seedlings that differed in tillering (low, medium, and high number of tillers per plant) retained similar rankings as

A.J. Smart, South Dakota State Univ., Dep. of Animal and Range Sci., Box 2170, Brookings, SD, 57007; and K.P. Vogel, USDA-ARS, 344 Keim Hall, P.O. Box 830937; L.E. Moser, Agronomy and Horticulture Dep., 279 Plant Sci., P.O. Box 830915; W.W. Stroup, Biometry Dep., 103 Miller Hall, Univ. of Nebraska, Lincoln, NE 68583. A contribution of the University of Nebraska Agricultural Research Division, Lincoln, NE 68583. Journal Series No.13768. Received 5 July 2002. *Corresponding author (alexander_smart@sdstate.edu).

Published in Crop Sci. 43:1427-1433 (2003). mature plants grown in pots or in sward conditions (Jones et al., 1979). Selection for seedling leaf development produced correlated responses in mature plant characteristics such as leaf length, leaf width, tiller number, and tiller weight in perennial ryegrass (Lolium perenne L.) (Edwards and Cooper, 1963). Four cycles of divergent selection for seedling tiller number in Altai wildrye [Leymus angustus (Trin.) Pilg.] successfully produced half-sib lines that differed in seedling tiller number, seedling height, tiller weight, and seedling dry matter yield (Jefferson et al., 2001). High tillering half-sib lines produced more dry matter yield per hectare in the second and third years after establishment than the low tillering half-sib lines at the nonirrigated site, but were not different at the irrigated site.

Vogel (1996, personal communication) observed that some seedlings of switchgrass, big bluestem, and indiangrass at 8 to $10 \mathrm{wk}$ after planting exhibited multiple tillering (three or more) while other seedlings produced only a single tiller. Both kinds of seedlings produced high shoot weight that was used to increase seedling vigor in three cycles of selection for high seedling shoot weight (Sebolai, 1989). This work raised questions about the variability of seedling tiller number found in big bluestem and switchgrass. Is seedling tiller number heritable? Does seedling tiller number affect seedling vigor and establishment? Does seedling tiller number affect mature plant characteristics? This paper will address the first question.

The objectives of this study were to determine the heritability and response to selection with two cycles of divergent selection for seedling tiller number while selecting for high shoot weight in seedlings of big bluestem and switchgrass 6 to 8 wk after planting.

\section{MATERIALS AND METHODS}

Divergent selection for tillering in big bluestem and switchgrass was conducted in the greenhouse at the USDAARS Forage Research Laboratory in Lincoln, NE, in the winter of 1996 (Cycle 1) and 1997 (Cycle 2). The base populations were Pawnee Seedling Vigor Cycle 3 big bluestem and Pathfinder Seedling Vigor Cycle 3 switchgrass, which were developed by selecting for high seedling shoot weight as described by Sebolai (1989). Plants were individually grown in supercell cone-tainers ${ }^{1}$ (Stuewe and Sons, Inc., Corvallis, OR) (22 $\mathrm{cm}$ deep, $3.8 \mathrm{~cm}$ in diameter at the top, and were kept in trays that held 98 cone-tainer cells). Each cone-tainer cell was filled with a mixture of soil, peat, and vermiculite at a volume

\footnotetext{
${ }^{1}$ Names of products are included for the benefit of the reader and does not imply endorsement by the USDA or the University of Nebraska.

Abbreviations: BBMT, big bluestem high seedling weight, multiple tiller; BBST, big bluestem high seedling weight, single tiller; SWMT, switchgrass high seedling weight, multiple tiller; SWST, switchgrass high seedling weight, single tiller.
} 
ratio of 2:1:1. Seeds were wet chilled at $5^{\circ} \mathrm{C}$ for $2 \mathrm{wk}$ to reduce dormancy and treated with Captan \{cis- $\mathrm{N}-[$ (trichloromethyl) thio-4-cyclohexene-1,2-dicarboximide]\} to prevent fungal growth before planting. Greenhouse temperatures were 30/ $20^{\circ} \mathrm{C}$ day/night and plants were grown under natural light conditions.

\section{Cycle 1 Selection}

Big bluestem and switchgrass base populations were seeded to 1960 cone-tainer cells each in the first cycle of selection. Four to five seeds were planted in each cone-tainer cell. One week after emergence each cone-tainer cell was thinned to one seedling. Seedlings were fertilized $3 \mathrm{wk}$ after planting with 20-20-20 $\left(\mathrm{N}-\mathrm{P}_{2} \mathrm{O}_{5}-\mathrm{K}_{2} \mathrm{O}\right)$ at a rate of $0.05 \mathrm{~kg} \mathrm{~m}^{-2}$. Big bluestem and switchgrass seedlings were individually harvested by clipping the plant $1 \mathrm{~cm}$ from the soil surface 6 and $7 \mathrm{wk}$, respectively, after planting. Fresh shoot weight and tiller number were recorded for each seedling. Divergent selection for tillering was done by selecting the 100 heaviest seedlings (based on fresh weight) that had a single tiller or multiple (three or more) tillers (Table 1). Seedlings were selected using stratified sampling for each species with five seedlings selected per conetainer tray. Selected plants were fertilized 4 to $5 \mathrm{wk}$ after selection at the previous rate and transplanted on 14 June 1996 into isolated crossing blocks consisting of 10 rows of 10 plants at a 1-m spacing at the Agricultural Research Development Center near Mead, NE. Crossing blocks were kept weed free by rototilling and a single post emergence application of atrazine [6-chloro-N-ethyl-N' -(1-methylethyl)-1,3,5-triazine2,4-diamine] at $2.24 \mathrm{~kg} \mathrm{ha}^{-1}$. The four crossing blocks were BBMT, BBST, SWMT, and SWST. Seed was harvested from individual plants to produce half-sib families in the crossing blocks on 15 and 24 October 1996 for switchgrass and big bluestem, respectively. Seed was cleaned and processed before the next cycle of selection.

\section{Cycle 2 Selection}

The second cycle of selection was conducted similar to the first except that the seed from single and multiple tiller Cycle 1 populations were planted separately to 14 cone-tainer cells per half-sib family. The BBMT and BBST Cycle 1 populations were planted to 1232 and 1218 cone-tainer cells, respectively. The SWMT and SWST Cycle 1 populations were planted to 1274 and 1386 cone-tainer cells, respectively. Plants were thinned and fertilized similar to the procedure used in the first cycle of selection. Big bluestem and switchgrass seedlings were individually harvested 8 wk after planting. Fresh weight and tiller number were recorded for each seedling. For each species, the 100 heaviest seedlings (based on fresh weight) that had a single tiller were selected within the single tiller Cycle 1 population and the 100 heaviest seedlings (based on fresh weight) that had three or more tillers were selected from the multiple tiller Cycle 1 population (Table 1). An attempt to select from each half-sib family was made; however, a small percentage of families were discarded because of extremely low seedling fresh weight. Selected plants were fertilized 4 to 5 wk after selection at the same rate as previously stated before transplanting into isolated crossing blocks. Weeds were controlled as previously described.

Base populations of 100 plants each for big bluestem and switchgrass were established in field isolations in 1997 specifically to produce seed for use in the evaluation trials to ensure seed of all entries was produced in the same year. Seed was bulk harvested from base, single tiller Cycle 1, multiple tiller Cycle 1, single tiller Cycle 2, and multiple tiller Cycle 2 populations for big bluestem and switchgrass in late September 1998 and 1999. Seed was cleaned and processed before greenhouse evaluation.

\section{Greenhouse Experiments}

Seed from the 1998 harvest consisted of the base population, single tiller Cycle 1, multiple tiller Cycle 1, single tiller Cycle 2 , and multiple tiller Cycle 2 populations of big bluestem and switchgrass. Seeds of each population were wet chilled at $5^{\circ} \mathrm{C}$ for 2 wk to reduce dormancy and treated with Captan before planting in two separate experiments, Exp. I in late January 1999, and Exp. II in late February 2000. In Exp. II, the 1998 seed for BBST Cycle 2 was depleted; therefore, 1999 seed of BBST Cycle 2 was used for this population. Greenhouse temperatures were $30 / 20^{\circ} \mathrm{C}$ day/night and plants were grown under natural light conditions.

The experimental design was a randomized complete block with eight replications for Exp. I and six replications for Exp. II. The experimental unit was a tray of 98 cone-tainer cells. Populations were planted, thinned, and fertilized in the same manner as previously described. Populations were harvested 8 wk after planting. Seedling shoot biomass was bulked for each cone-tainer tray in 1999 and 2000. Tiller number from each seedling was recorded. Mean tiller number was calculated by averaging tiller number per seedling. Fresh shoot weight per seedling was calculated by dividing bulk seedling shoot biomass by number of seedlings per cone-tainer tray.

Table 1. Number of plants $(n)$, mean tiller number $(T)$, seedling shoot weight $(\mathrm{SW})$, standard deviation (SD), and selection differential (SED) of populations used to develop big bluestem and switchgrass populations with two cycles of divergent selection for seedling tiller number while selecting for high shoot weight 6 to 8 wk after planting.

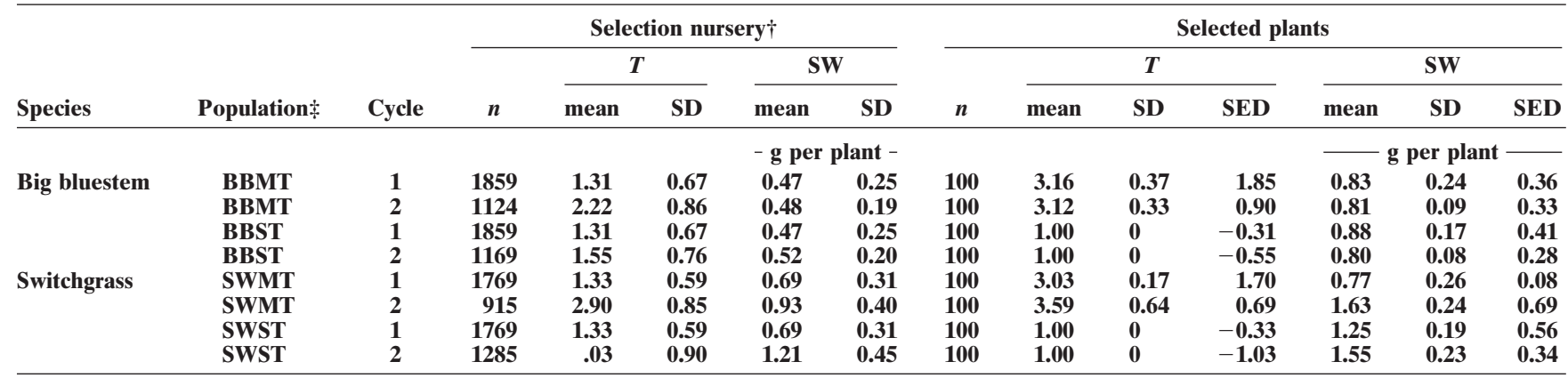

$\dagger$ Selection nursery for BBMT Cycle 1 and BBST Cycle 1 are the same population. Selection nursery for SWMT Cycle 1 and SWST Cycle 1 are the same population.

$¥$ Population BBMT is big bluestem multiple tiller, BBST is big bluestem single tiller, SWMT is switchgrass multiple tiller, and SWST is switchgrass single tiller. 
Analysis of variance was conducted on mean tiller number and mean fresh weight per seedling using the PROC GLM of the SAS Institute (1999). Sources of variation were experiment, block within experiment, population, and experiment $\times$ population interaction. Experiment was considered a random effect and population was considered a fixed effect. Separate analyses were conducted for each species because they were planted in separate experiments. Single degree of freedom orthogonal contrasts were made to compare multiple tiller populations vs. single tiller populations and Cycle 1 vs. Cycle 2 within multiple tiller and single tiller populations. An $\alpha$ level of 0.05 was used as the criteria for mean differences to be considered statistically significant. Number of plants having one, two, three, four, or five tiller(s) per seedling were analyzed as multinomial categorical data with a proportional odds model. Estimated probability distributions with standard errors for number of tillers per plant were obtained using PROC NLMIXED of SAS and log odds-ratio parameter estimates with standard errors and $\chi^{2}$ tests of seedling tiller number were obtained using PROC LOGISTIC of the SAS Institute (1999).

Realized heritability estimates for tillering and fresh weight were obtained by regressing cycle means from evaluation experiments for the five populations of each species with the accumulated selection differential for each cycle of selection (Falconer and Mackay, 1996):

$$
h^{2}=b_{\mathrm{h}}=R / S \text {, }
$$

where $b$ is the slope measured from the response $(R)$ of the offspring against the accumulated selection differential $(S)$ of the parents. Gain from selection was calculated for tillering and fresh weight by regressing population means on cycle of selection:

$$
G=b_{\mathrm{g}}=R / C
$$

where $b$ is the slope measured from the response $(R)$ of the offspring (population mean) against cycle of selection $(C)$.

\section{RESULTS AND DISCUSSION Population Evaluation}

Phenotypic variation existed in the big bluestem and switchgrass base, Cycle 1, and Cycle 2 populations for both fresh shoot weight and tiller number of seedlings (Table 1). Selection differentials were large except for seedling weight for the switchgrass multiple tiller Cycle 1 population (Table 1). In the analyses of the greenhouse experiments in which gain from selection was evaluated, there was no experiment by population interactions for fresh shoot weight and mean tiller number of big bluestem (analysis not shown). There was an experiment $\times$ population interaction for switchgrass mean tiller number; however, it only accounted for $4 \%$ of the total variation. Divergent selection significantly changed mean seedling tiller numbers for both switchgrass and big bluestem populations (Tables 2, 3). In the big bluestem populations, mean seedling tiller number changed with each cycle of divergent selection (Table 2). In the switchgrass populations, mean seedling tiller number increased after one cycle of multiple tiller selection, but an additional increase did not occur following Cycle 2 (Table 3). Switchgrass mean seedling tiller number decreased with two cycles of single tiller selection.

The single tiller Cycle 2 populations had greater shoot weight per plant than the other populations for both
Table 2. Mean tiller number and shoot weight averaged across two breeding progress evaluation experiments of big bluestem populations developed by two cycles of divergent selection for seedling tiller number while selecting for high shoot weight 6

\begin{tabular}{|c|c|c|c|}
\hline Population $\dagger$ & Cycle & $\begin{array}{l}\text { Mean tiller } \\
\text { number }\end{array}$ & $\begin{array}{l}\text { Shoot } \\
\text { weight }\end{array}$ \\
\hline & & & g per plant \\
\hline Base & $\mathbf{0}$ & 1.77 & 0.23 \\
\hline BBMT & 1 & 2.16 & 0.26 \\
\hline BBMT & 2 & 2.29 & 0.29 \\
\hline BBST & $\mathbf{1}$ & 1.51 & 0.29 \\
\hline BBST & 2 & 1.31 & 0.40 \\
\hline \multicolumn{2}{|c|}{ Orthogonal contrast } & \multicolumn{2}{|c|}{$P$ value } \\
\hline \multicolumn{2}{|c|}{$\begin{array}{l}\text { Multiple-tiller vs. single-tiller } \\
\text { populations }\end{array}$} & $<0.01$ & $<0.01$ \\
\hline \multicolumn{2}{|c|}{ Cycle 1 multiple tiller vs. } & 0.05 & 0.02 \\
\hline $\begin{array}{l}\text { Cycle } 1 \text { single } \\
\text { Cycle } 2 \text { sin } \\
\text { population }\end{array}$ & & $<0.01$ & \\
\hline \multicolumn{2}{|c|}{$\begin{array}{l}\text { population } \\
\text { Least significant difference }\end{array}$} & 012 & 0.02 \\
\hline Coefficient of & & 12 & 14 \\
\hline
\end{tabular}
to 8 wk after planting.

† Base population is Seedling Vigor Cycle 3 'Pawnee' big bluestem, BBMT is big bluestem multiple tiller, and BBST is big bluestem single tiller.

species (Tables 2, 3). In Altai wildrye, with festicoid seedling morphology, half-sib lines divergently selected for seedling tiller number were different in seedling dry weight (Jefferson et al., 2001). Low-tillering lines had greater seedling dry matter than high-tillering lines and the base population when grown under irrigated conditions. However, both selected lines had less seedling dry matter than the base population under dryland conditions (Jefferson et al., 2001).

Divergent selection for seedling tiller number shifted the frequency of occurrence of seedlings having one, two, three, four, or five tiller(s) from the base population 6 to 8 wk after planting in big bluestem and switchgrass (Fig. 1, 2). All selected populations had different $(P<$ 0.01 ) frequencies of number of tillers per plant com-

Table 3. Mean tiller number and shoot weight averaged across two breeding progress evaluation experiments of switchgrass populations developed by two cycles of divergent selection for seedling tiller number while selecting for high shoot weight 6

\begin{tabular}{|c|c|c|c|}
\hline Population $\dagger$ & Cycle & $\begin{array}{l}\text { Mean tiller } \\
\text { number }\end{array}$ & $\begin{array}{l}\text { Shoot } \\
\text { weight }\end{array}$ \\
\hline & & & g per plant \\
\hline Base & 0 & 1.62 & 0.39 \\
\hline SWMT & 1 & 2.05 & 0.39 \\
\hline SWMT & 2 & 2.01 & 0.41 \\
\hline SWST & 1 & 1.41 & 0.45 \\
\hline SWST & 2 & 1.23 & 0.52 \\
\hline \multicolumn{2}{|c|}{ Orthogonal contrast } & \multicolumn{2}{|c|}{$P$ value } \\
\hline \multicolumn{2}{|c|}{$\begin{array}{l}\text { Multiple tiller vs. single tiller } \\
\text { populations }\end{array}$} & $<0.01$ & $<0.01$ \\
\hline \multicolumn{2}{|c|}{$\begin{array}{l}\text { Cycle } 2 \text { multiple tiller } \\
\text { population }\end{array}$} & 0.41 & 0.33 \\
\hline \multicolumn{2}{|c|}{ Cvcle 1 single tiller vs. Cvcle } & & \\
\hline \multicolumn{2}{|c|}{2 single tiller population } & $<0.01$ & $<0.01$ \\
\hline \multicolumn{2}{|c|}{ Least significant difference } & 0.08 & 0.04 \\
\hline \multicolumn{2}{|c|}{ Coefficient of variation } & 7 & 14 \\
\hline
\end{tabular}
to 8 wk after planting.

† Base population is Seedling Vigor Cycle 3 'Pathfinder' switchgrass, SWMT is switchgrass multiple tiller, and SWST is switchgrass single tiller. 


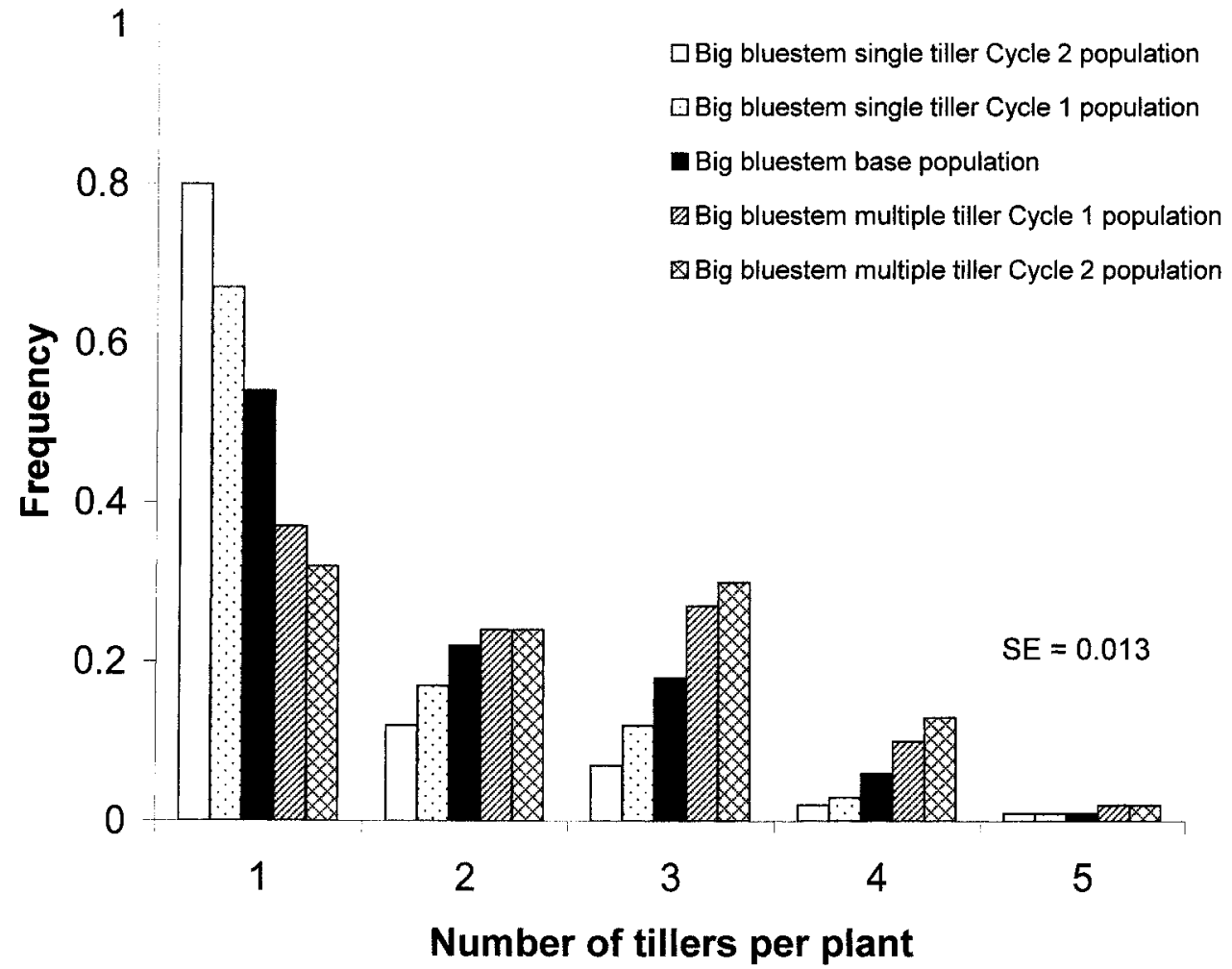

Fig. 1. Estimated frequency distribution of number of tillers per plant averaged across two experiments of big bluestem populations developed by two cycles of divergent selection for seedling tiller number while selecting for high shoot weight 6 to 8 wk after planting.

pared with the base population as indicated by $\chi^{2}$ tests of the log odds-ratio parameter of population and cycle vs. the base population (analysis not shown). Significant $\chi^{2}$ tests, indicated by a single degree of freedom contrasts comparing multiple vs. single tiller populations within a cycle of selection, all showed that the frequency distributions between these populations were different $(P<$ $0.01)$ at each cycle of selection for both big bluestem

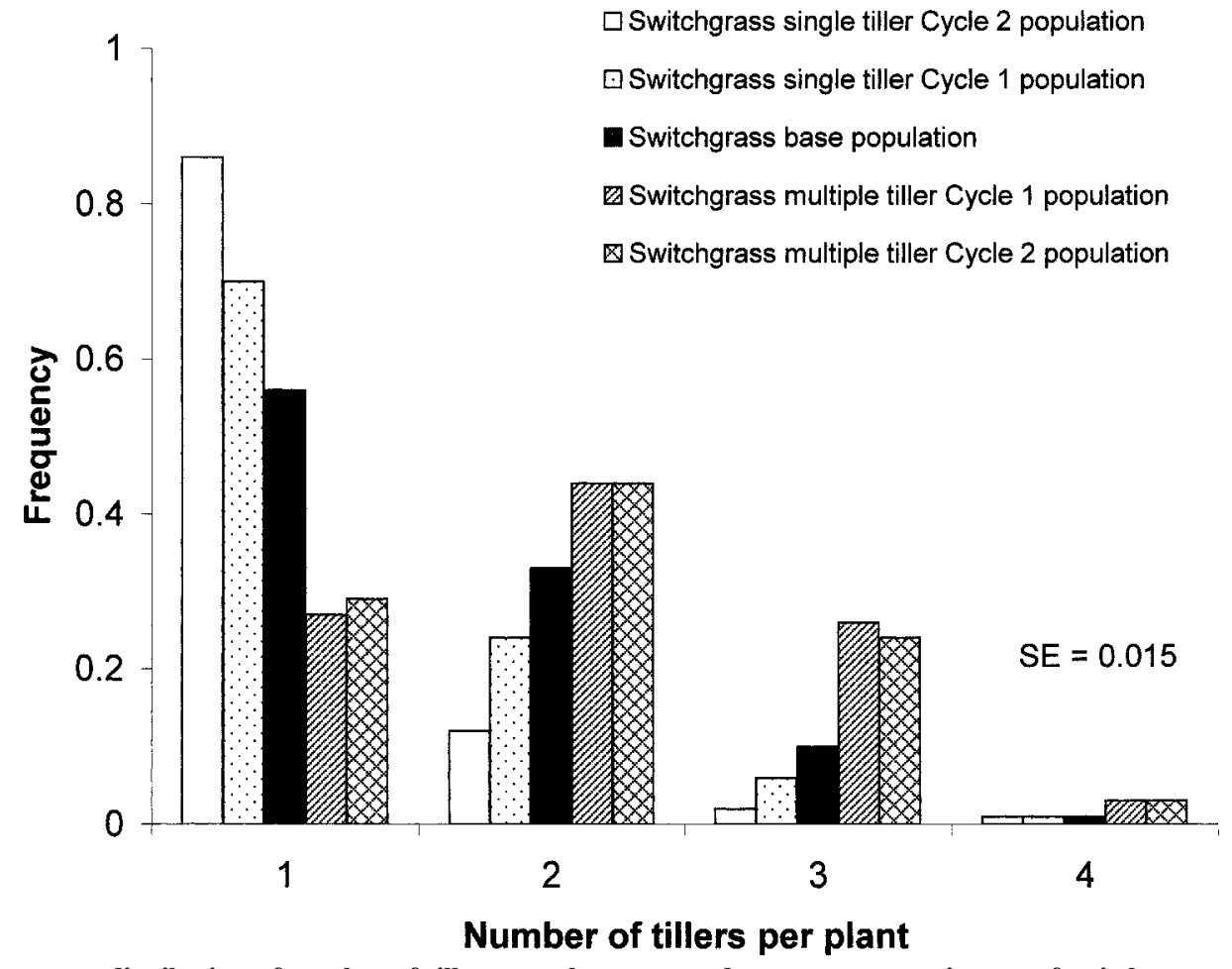

Fig. 2. Estimated frequency distribution of number of tillers per plant averaged across two experiments of switchgrass populations developed by two cycles of divergent selection for seedling tiller number while selecting for high shoot weight 6 to 8 wk after planting. 
and switchgrass (analysis not shown). Single tiller Cycle 2 populations deviated more from the single tiller Cycle 1 populations as indicated by the large $\chi^{2}=48.9(P<$ $0.01)$ from the contrast between BBST-C1 vs. BBST$\mathrm{C} 2$ and $\chi^{2}=76.8(P<0.01)$ from the contrast between SWST-C1 vs. SWST-C2. Big bluestem multiple tiller Cycle 2 population deviated from BBMT-C1 $\left(\chi^{2}=9.5\right.$, $P<0.010)$; however, the difference between SWMT$\mathrm{C} 1$ and SWMT-C2 $\left(\chi^{2}=1.7, P=0.20\right)$ was not significant. Thus, it appears from these data that an additional cycle of selection for multiple tillers per plant in big bluestem and switchgrass had little impact on changing the frequency distribution of the number of tillers per plant.

It is unclear why a second cycle of selection for multiple tillers did not have as great a change on the frequency distribution of the number of tillers per plant as a second cycle for single tillers. The selection differential was about half as large in Cycle 2 than it was in Cycle 1 for mean tiller number in the multiple tiller populations, while it was greater in Cycle 2 than in Cycle 1 for single tiller populations in both big bluestem and switchgrass (Table 1). The role of nutrient availability and plant hormonal activity in controlling apical dominance and tillering has been thoroughly reviewed (Murphy and Briske, 1992). Perhaps multiple tiller seedlings have reduced apical dominance due to reduced hormonal activity. Thus, reduced hormonal activity for multiple tiller plants might have been influenced by environmental variables, that might occur in a greenhouse setting in ambient wintertime light, more than for single-tiller seedlings that have an inherent higher level of hormonal activity.

Differences in the distribution of seedling tiller numbers (Fig. 1,2) suggest that the percentage of single tiller plants in the population have the largest influence on mean seedling shoot weight yield per plant (Tables 2, 3). Sebolai (1989) demonstrated that three cycles of recurrent phenotypic selection for high seedling shoot weight in switchgrass, big bluestem, and indiangrass increased mean seedling shoot weight, but seedling tiller number was not evaluated. They may have inadvertently selected for single-tiller seedlings while selecting for high shoot weight. In the current study, only the single tiller populations had a significant increase in fresh shoot weight (Tables 2, 3). Cattani and Struik (2001) showed that the dry weight per tiller of the main stem and primary tillers was greater for creeping bentgrass \{Agrostis palustris Huds. [= A. stolonifera var. palustris
(Huds.)Farw.]\} seedlings of a low-tiller density population ('Emerald') vs. a high-tiller density population ('UM67-10'). The population Emerald also had higher dry weight per plant than UM67-10. Their data indicated that the main stem and primary tillers of Emerald were stronger sinks compared with UM67-10 because of steeper slopes in dry matter weight accumulation per tiller age. They attributed this difference to larger leaves, tillers, and elongating stems of Emerald. This similar relationship has also been seen in tall fescue (Jones et al., 1979), perennial ryegrass (Cooper and Edwards, 1961; Edwards and Cooper, 1963), and Altai wildrye (Jefferson et al., 2001) genotypes or populations that differed in number of tillers per plant.

\section{Heritability and Gain from Selection}

Seedling tiller number in big bluestem and switchgrass had relatively high realized heritability estimates (Table 4). The lower standard error, lower root mean square error, and higher $r^{2}$ values from the regression analysis suggest that the inheritance of seedling tiller number in big bluestem was more predictable than in switchgrass (Table 4). Lower realized heritability estimate for seedling tiller number in switchgrass was caused by the experiment $\times$ population interaction for mean tiller number. Switchgrass seedlings were more morphologically advanced in Exp. II than in Exp. I. When realized heritability was calculated for switchgrass seedling tiller number separately for each experiment, $r^{2}$ values were 0.97 in Exp. I and 0.91 in Exp. II. Cooper and Edwards (1961) also calculated high heritability estimates ( 0.43 to 0.79$)$ for seedling tiller number in perennial ryegrass varieties from full-sib progeny tests. They determined that considerable variability for seedling traits in perennial ryegrass existed in commercial cultivars from which they made their selections. A lower estimate of heritability (0.27) was determined from the sum of the sire-offspring and damoffspring correlations of seedling tiller number in an Australian commercial population of Phalaris tuberosa L. (= P. aquatica L.) (Latter, 1971).

Realized heritability estimates for seedling fresh shoot weight of big bluestem and switchgrass were low (Table 4). The standard errors of the regression coefficient were high and the $r^{2}$ values were low. Fresh seedling shoot weight was less heritable than seedling tiller number. Latter (1971) had a similar estimate of heritability (0.17) for seedling dry weight in P. tuberosa. How-

Table 4. Realized heritability for seedling tiller number and fresh shoot weight averaged across two experiments of populations of big bluestem and switchgrass developed by two cycles of divergent selection for seedling tiller number while selecting for high shoot weight 6 to 8 wk after planting.

\begin{tabular}{lllllrr}
\hline Species & Trait & $h^{2} \dagger$ & SE $\ddagger$ & $r^{2} \S$ & $P$ value & RMSEI \\
\hline Big bluestem & Tiller number & $\mathbf{0 . 2 6}$ & $\mathbf{0 . 0 3}$ & $\mathbf{0 . 9 2}$ & $\mathbf{0 . 0 1}$ & $\mathbf{0 . 1 2}$ \\
& Fresh weight, $\mathrm{g}$ & $\mathbf{0 . 1 7}$ & $\mathbf{0 . 1 4}$ & $\mathbf{0 . 1 6}$ & $\mathbf{0 . 1 1}$ \\
Switchgrass & Tiller number & $\mathbf{0 . 2 3}$ & $\mathbf{0 . 0 9}$ & $\mathbf{0 . 4 6}$ & $\mathbf{0 . 0 3}$ & $\mathbf{0 . 3 8}$ \\
& Fresh weight, $\mathrm{g}$ & $\mathbf{0 . 0 2}$ & $\mathbf{0 . 1 3}$ & $\mathbf{0 . 0 1}$ & $\mathbf{0 . 2 0}$ \\
\hline
\end{tabular}

$\dagger h^{2}=b_{\mathrm{h}}=$ regression of cycle mean on accumulated selection differential.

$\$$ Standard error of estimate of regression coefficient.

$\S$ Coefficient of simple determination of regression.

Il Root mean square error of regression. 
Table 5. Gain from selection for mean tiller number and fresh shoot weight averaged across two experiments of populations of big bluestem and switchgrass developed by two cycles of divergent selection for seedling tiller number while selecting for high shoot weight 6 to 8 wk after planting.

\begin{tabular}{|c|c|c|c|c|c|}
\hline Trait & Gain per cycle $\dagger$ & SE & $r^{2} \S$ & $P$ value & RMSEII \\
\hline \multicolumn{6}{|c|}{ Big bluestem } \\
\hline Mean tiller number, multiple tiller populations & 0.26 & 0.04 & 0.49 & $<0.01$ & 0.22 \\
\hline Mean tiller number, single tiller populations & -0.22 & 0.03 & 0.55 & $<0.01$ & 0.17 \\
\hline Fresh weight per plant of multiple tiller populations, $g$ & $\mathbf{0 . 0 3}$ & 0.02 & 0.05 & 0.17 & 0.10 \\
\hline Fresh weight per plant of single tiller populations, $g$ & 0.08 & 0.02 & 0.32 & $<0.01$ & 0.10 \\
\hline \multicolumn{6}{|c|}{ Switchgrass } \\
\hline Mean tiller number, multiple tiller populations & 0.19 & 0.08 & 0.12 & 0.02 & 0.44 \\
\hline Mean tiller number, single tiller populations & $-\mathbf{0 . 1 8}$ & 0.06 & 0.21 & $<0.01$ & 0.30 \\
\hline Fresh weight per plant of multiple tiller populations, $g$ & 0.01 & 0.04 & 0.01 & 0.81 & 0.19 \\
\hline Fresh weight per plant of single tiller populations, $g$ & 0.06 & 0.04 & 0.07 & 0.08 & 0.19 \\
\hline
\end{tabular}

$\uparrow$ Gain per cycle $=G=b_{\mathrm{g}}=$ regression of cycle mean on cycle of selection.

$\uparrow$ Standard error of estimate of regression coefficient.

$\$$ Coefficient of simple determination of regression.

II Root mean square error of regression.

ever, Cooper and Edwards (1961) estimated heritability for dry weight per plant for varying perennial ryegrass varieties from full-sib progeny tests to range from 0.28 to 0.57 .

Gain from selection for mean seedling tiller number was significant for big bluestem and switchgrass for both multiple and single tiller selection (Table 5). Further gain in selection may be possible for seedling tiller number because the realized heritability estimates of seedling tiller number in big bluestem and switchgrass were 26 and $23 \%$, respectively. Populations with few and many tillers per seedling can be developed using recurrent phenotypic selection for seedling tiller number.

Although small, gain in fresh weight per plant was significant for single tiller selection compared with the base population but insignificant for multiple tiller selection for big bluestem and switchgrass (Table 5). The results clearly indicate that seedling shoot weight can be improved in big bluestem and switchgrass by selecting for large, single-tiller seedlings.

\section{Implications}

Field evaluation trials need to be conducted to determine if the genetic change in seedling tiller number and seedling weight results in improved establishment under field conditions. Deep planting screening methods used to develop improved varieties of cool-season grasses like 'Swift' Russian wildrye [Psathyrostachys juncea (Fisch.) Nevski] (Lawrence, 1979b) are not useful techniques to improve seedling vigor in warm-season grasses because most warm-season grasses have a panicoid-type seedling emergence (Hyder et al., 1971) which always places the site of adventitious root development near the soil surface compared with cool-season grasses which develop adventitious roots near the site of seed placement. Selecting for seedling weight, as was done in this study, has been shown to be a proven method for improving seedling vigor in sand bluestem (Andropogon hallii Hack.) (Glewen and Vogel, 1984).

Differences in the number of tillers per seedling from these populations needs to be evaluated at the mature plant level to determine their effects on morphological characteristics. If the number of tillers per seedling ex- pressed in these divergent populations of big bluestem and switchgrass maintains similar rankings at the mature plant level, then morphological plant characteristics should be different. Jones et al. (1979) showed that tall fescue seedlings differing in number of tillers were very different in leaf length, leaf width, leaf area expansion rate, yield per tiller, and yield per plant. Sward yields were greater for low yield per tiller tall fescue genotypes when harvested early in the growing season because number of tillers was more important in determining yield than yield per tiller, but the opposite was true for harvest dates later in the growing season. Therefore, selection at the seedling level for number of tillers per plant may be useful in developing big bluestem and switchgrass populations for specific management objectives.

\section{REFERENCES}

Cattani, D.J., and P.C. Struik. 2001. Tillering, internode development, and dry matter partitioning in creeping bentgrass. Crop Sci. 41: $111-118$.

Cooper, J.P., and K.J.R. Edwards. 1961. The genetic control of leaf development in Lolium. I. Assessment of genetic variation. Heredity $16: 63-82$.

Edwards, K.J.R., and J.P. Cooper. 1963. The genetic control of leaf development in Lolium. II. Response to selection. Heredity 18:307317.

Falconer, D.S., and T.F.C. Mackay. 1996. Introduction to quantitative genetics. 4th ed. Longman Group, Essex, UK.

Glewen, K.L., and K.P. Vogel. 1984. Partitioning the genetic variability for seedling growth in sand bluestem into its seed size and seedling vigor components. Crop Sci. 24:137-141.

Hayward, M.D., and T. Lawrence. 1970. Genetic control of variation in a selected population of Lolium perenne L. Can. J. Genet. Cytol. 12:806-815.

Hyder, D.N., A.C. Everson, and R.E. Bement. 1971. Seedling morphology and seeding failures with blue grama. J. Range Manage. 24:287-292.

Jefferson, P.G., T. Lawrence, and G.A. Kielly. 2001. Divergent recurrent selection for seedling tiller number in Altai wildrye. Grass Forage Sci. 56:285-293.

Jones, R.J., C.J. Nelson, and D.A. Sleper. 1979. Seedling selection for morphological characters associated with yield of tall fescue. Crop Sci. 19:631-634.

Latter, B.H.D. 1971. Quantitative genetic analysis in Phalaris tuberosa III. Maternal effects on seedling growth and development. Genet. Res. 18:245-253.

Lawrence,T. 1979a. Swift, Russian wild ryegrass. Can. J. Plant Sci. 59:515-518. 
Lawrence, T. 1979b. Genetic control of variation in a selected population of Altai wild ryegrass (Elymus angustus). Can. J. Plant Sci. 59:7-13.

Murphy, J.S., and D.D. Briske. 1992. Regulation of tillering by apical dominance: Chronology, interpretive value, and current perspectives. J. Range Manage. 45:419-429.

Nelson, C.J., and D.A. Sleper. 1980. Morphological characters associated with productivity of tall fescue. p. 177-179. In E. Wojahn and H. Thöns (ed.) Proc. 13th Int. Grassl. Congr., Leipzig, German Democratic Republic. 18-27 May 1977. Akedemie-Verlag, Berlin. SAS Institute. 1999. SAS OnLine Doc, Version 8. SAS Inst., Cary, NC. Sebolai, B. 1989. Evaluation of three cycles of stratified mass selection for high seedling shoot weight in three warm-season grasses. M.S. Thesis. Univ. of Nebraska, Lincoln, NE.

Simons, R.G. 1990. Relationships between seedling traits and mature plant yield in alfalfa. Can. J. Plant Sci. 69:209-213.

Trupp, C.R., and I.T. Carlson. 1971. Improvement of seedling vigor of smooth bromegrass (Bromus inermis Leyss.) by recurrent selection for high seed weight. Crop Sci. 11:225-228.

Twamley, B.E. 1974. Recurrent selection for seedling vigor in birdsfoot trefoil. Crop Sci. 14:87-90.

Xie, C., and J.A. Mosjidis. 1995. Seedling-selection effects on morphological traits of mature plants in red clover. Theor. Appl. Genet. 91:1032-1036. 